\title{
Efektivitas Penyelesaian Tindak Pidana Ringan Melalui Lembaga Adat (Sarak Opat)
}

\author{
Achmad Surya dan Suhartini \\ Fakultas Ilmu Sosial dan Ilmu Politik Universitas Gajah Putih dan \\ Sekolah Tinggi Ilmu Hukum Muhammadiyah Takengon \\ Jl. Takengon-Isaq, Belang Bebangka, Ke. Pegasing, Takengon, Aceh \\ surya_gayo85@yahoo.co.id; suhartini.gayo@gmail.com
}

Received: 25 Oktober 2018; Accepted: 26 Desember 2018; Published: 24 April 2019

DOI: 10.20885/iustum.vol26.iss1.art5

\begin{abstract}
This study aims firstly to observe the effectiveness of minor criminal acts settlement through Sarak Opat in Central Aceh District. Second, it is to find out what constraints being faced by Sarak Opat are in settling the minor criminal acts in Central Aceh District. The method used in this study was empirical legal research or sociological legal research. The types and sources of data used in this study included library research and field research. The data analysis technique was conducted through a descriptive qualitative method by analysing the data obtained from the primary and secondary data sources. This was then continued with a thorough discussion and a conclusion, based on the discussion, was drawn in response to the problems studied. The results of the research showed first that it was still ineffective now that the people becoming the victims of criminal acts more believed in the police as the law enforcement officials rather than the settlement through the traditional institution of Sarak Opat. Second, the constraints faced by Sarak Opat in the settlement of minor crimes in Central Aceh Regency, included 1). The lack of understanding of the traditional institution of Sarak Opat; 2). Customary sanctions not giving any deterrent effects on the perpetrator; 3). No documented dispute settlement by traditional institution Sarak Opat; 4). Lack of coordination between traditional institution Sarak Opat and Police Department.
\end{abstract}

Keywords: Effectiveness; minor criminal acts; sarak opat

\begin{abstract}
Abstrak
Tujuan penelitian ini, pertama, untuk mengetahui efektivitas penyelesaian tindak pidana ringan melalui sarak opat di Kabupaten Aceh Tengah. Kedua, untuk mengetahui apakah kendala yang dihadapi sarak opat dalam penyelesaian tindak pidana ringan di Kabupaten Aceh Tengah. Matode yang digunakan dalam penelitian ini adalah penelitian hukum empiris atau penelitian hukum sosiologis. Jenis dan Sumber data yang digunakan dalam penelitian ini yakni penelitian pustaka (library research) dan penelitian lapangan (field research). Teknik analisis data, dianalisis dengan metode deskriptif kualitatif dengan menganalisis data yang diperoleh dari sumber data primer maupun sekunder, setelah itu dilakukan pembahasan secara menyeluruh, dan berdasarkan pembahasan tersebut diambil suatu kesimpulan sebagai jawaban atas permasalahan yang diteliti. Hasil penelitian menyimpulkan, pertama, belum efektifnya karena masyarakat yang menjadi korban dari perbuatan pidana lebih percaya kepada aparat penegak hukum (kepolisian) dibandingkan dengan penyelesaian melalui lembaga adat sarak opat. Kedua, kendala yang dihadapi sarak opat dalam penyelesaian tindak pidana ringan di Kabupaten Aceh Tengah, yaitu: 1). Kurangnya pemahaman perangkat lembaga adat sarak opat; 2). Sanksi adat tidak memberikan efek jera terhadap pelaku; 3). Tidak terdokumentasikannya penanganan perkara/kasus oleh lembaga adat sarak opat; 4). Kurangnya koordinasi lembaga adat sarak opat dengan pihak Kepolisian.
\end{abstract}

Kata-kata Kunci: Efektifitas; tindak pidana ringan; sarak opat 


\section{Pendahuluan}

Undang-Undang Dasar Tahun 1945 Pasal 18B ayat (2) menegaskan bahwa Negara mengakui dan menghormati kesatuan-kesatuan masyarakat hukum adat beserta hak-hak tradisionalnya sepanjang masih hidup dan sesuai dengan perkembangan masyarakat dan prinsip Negara Kesatuan Republik Indonesia (NKRI) yang diatur dalam undang-undang. Jaminan konstitusional merupakan dasar hukum yang sangat kuat bagi kesatuan masyarakat hukum adat. Namun, untuk dapat tetap bertahan dan eksis tentu diperlukan upaya revitalisasi, baik oleh negara melalui instrumen hukum, upaya secara akademis, maupun upaya nyata terhadap kesatuan masyarakat hukum adat itu sendiri". ${ }^{1}$

Hukum adat menurut sistem hukum Indonesia disebut dengan hukum tidak tertulis (unstatuta law) yang berbeda dengan hukum tertulis (statuta law). Perbedaannya adalah bahwa hukum tertulis dibuat dengan kata-kata yang tidak dapat berubah tanpa diadakannya suatu perubahan sehingga hukum tertulis tidak mencerminkan lagi apa yang hidup dalam masyarakat. Sedangkan hukum adat merupakan produk dari budaya yang mengandung substansi tentang nilai-nilai budaya sebagai cipta dan rasa manusia, yang artinya adalah bahwa hukum adat tumbuh berkembang mengikuti pola pikir dan pola hidup yang hidup dalam masyarakat. Hukum adat lahir dari kesadaran atas kebutuhan dan keinginan manusia untuk hidup secara adil dan beradab sebagai aktualisasi peradaban manusia. ${ }^{2}$

Hukum adat merupakan produk sosial yaitu sebagai hasil kerja bersama (kesepakatan) dan merupakan karya bersama secara bersama (milik sosial) dari suatu masyarakat hukum adat. Pemberlakuan hukum adat di Indonesia sangatlah beragam, setiap daerah mempunyai hukum adat tersendiri dan berbeda satu sama lainnya. Mulai dari yang secara jelas sangat dekat dengan hukum Islam sampai pada yang masih menganut anismisme, ada hukum adat yang menganut patrilineal, matrilineal namun juga ada yang menganut sistem parental. ${ }^{3}$ Van Vollenhoven membagi 19 lingkaran hukum adat di Indonesia, yaitu Aceh, Gayo,

\footnotetext{
${ }^{1}$ Soerjono Soekanto, Masalah Kedudukan dan Peranan Hukum Adat, Academica, Jakarta, 1971, hlm. 12.

2 Djamanat Samosir, Hukum Adat Indonesia Eksistensi Dalam Dinamika Perkembangan Hukum di Indonesia, Nuansa Aulia, Bandung, 2013, hlm. 1.

${ }^{3}$ Soerojo Wignjodipoero, Pengantar Dan Asas-Asas Hukum Adat, PT Toko Gunung Agung, Bandung, 1967, hlm. 89 .
} 
Minangkabau, Sumatera Selatan, Melayu, Bangka-Belitung, Kalimantan, Minahasa, Gorontalo, Toraja, Sulawesi Selatan, Ternate, Maluku, Irian, Timor, Bali dan Lombok, Jawa Tengah dan Jawa Timur Solo, Yogyakarta dan Jawa Barat. ${ }^{4}$

Dalam masyarakat hukum adat sudah sejak lama sengketa-sengketa yang terjadi diselesaikan secara musyawarah dan mufakat melalui lembaga-lembaga adat seperti peradilan desa atau yang disebut dengan peradilan adat. Tedy Sudrajat, menyatakan secara khusus peranan hakim perdamaian desa sebagai wadah untuk mengakomodir kepentingan masyarakatnya dalam upaya menuju hukum yang progresif. ${ }^{5}$ Biasanya yang bertindak sebagai hakim dalam lembaga tersebut adalah tokoh-tokoh adat (kepala adat) dan tokoh agama. Kewenangan dari hakim peradilan adat ini tidak semata-mata terbatas pada perdamaian saja, tetapi juga kekuasaan memutus sengketa dalam semua bidang hukum yang tidak terbagi ke dalam pengertian pidana, perdata, publik, dan lain-lain.

Sebagai salah satu media penyelesaian sengketa alternatif, eksistensi peradilan adat merupakan langkah positif dalam mewujudkan keadilan di masyarakat. Konsep hukum adat dan peradilan adat sejatinya adalah akar keadilan restoratif. ${ }^{6}$ Di Aceh penyelesaian kasus dalam kehidupan masyarakat banyak diselesaikan melalui Peradilan Adat atau yang lebih dikenal dengan Lembaga Adat. Lembaga adat ini bisa diwujudkan melalui pengejawantahan pranata sosial sebagai pageu gampong (pagar kampung). ${ }^{7}$ Tujuan dari peradilan adat adalah untuk menciptakan kedamaian dan keharmonisan hidup masyarakat, bukan untuk memutuskan kalah atau menang. Bahkan pada kasus-kasus tertentu sebagian masyarakat Aceh meletakkan posisi lembaga adat lebih tinggi tingkatannya dibandingkan lembaga pengadilan formal. ${ }^{8}$

Keberadaan peradilan adat di Aceh diakui oleh sejumlah peraturan dan kebijakan daerah. Bahkan Keputusan Bersama Gubernur Aceh, Kepala Kepolisian

\footnotetext{
${ }^{4}$ Ibid.,

${ }^{5}$ Tedy Sudrajat, Aspirasi "Reformasi Hukum dan Penegakan Hukum Progresif Melalui Hakim Perdamaian Desa”, artikel dalam Jurnal Dinamika Hukum, Volume 10 No 3 Desember 2010, hlm. 291-300.

' Ahmad Ubbe, "Peradilan Adat dan Keadilan Restoratif', artikel dalam Jurnal Rechtsvinding, Volume 2 No. 2 Agustus 2013, hlm. 163

${ }^{7}$ Syahrizal, Hukum Adat dan bukum Islam di Indonesia, Nadiya Foundation Nanggroe Aceh, Banda Aceh, 2004, hlm. 63.

8 Kamaruddin, "Model Penyelesaian Konflik Di Lembaga Adat", artikel dalam Walisongo : Jurnal Penelitian Sosial Keagamaan, Volume 21 No. 1 Mei 2013.
} 
Daerah Aceh Dan Ketua Majelis Adat Aceh Nomor: 189/677/2011, 1054/MAA/XII/2011, B/121/I/2012 tentang Penyelenggaraan Peradilan Adat Gampong Dan Mukim Atau Nama Lain Di Aceh, pada bagian Kesatu menyebutkan secara tegas sengketa/perselisihan yang terjadi di tingkat Gampong dan Mukim yang bersifat ringan wajib diselesaikan terlebih dahulu melalui Peradilan Adat atau lembaga adat. ${ }^{9}$ Bagi masyarakat di Kabupaten Aceh Tengah, dalam penyelesaian perkara/perselisihan yang terjadi di dalam masyarakat diselesaikan oleh lembaga adat yang disebut Sarak Opat, yang terdiri dari Reje, Imem, Petue, dan Rakyat Genap Mupakat (RGM). ${ }^{10}$

Tindak pidana ringan yang dapat diselesaikan oleh lembaga adat sarak opat sebagaimana diamanatkan Pasal 13 ayat (1) Qanun Aceh Nomor 9 Tahun 2008 tentang Pembinaan Kehidupan Adat Dan Adat Istiadat yang dapat diselesaikan secara adat melalui lembaga adat, yaitu: perselisihan dalam rumah tangga; perselisihan antar warga; khalwat (mesum); pencurian dalam keluarga (pencurian ringan); pencurian ringan; pencurian ternak peliharaan; penganiayaan ringan; pembakaran hutan (dalam skala kecil yang merugikan komunitas adat); pelecehan, fitnah, hasut, pencemaran nama baik dan ancam mengancam (tergantung dari jenis ancaman). ${ }^{11}$

Namun dalam prakteknya, peneliti menjumpai beberapa kasus seperti perselisihan dalam rumah tangga, pencurian ternak, dan penganiayaan ringan diselesaikan oleh aparat penegak hukum atau diselesaikan secara peradilan formal. Hal tersebut bertentangan dengan amanat Pasal 13 ayat (3) Qanun Aceh Nomor 9 Tahun 2008 tentang Pembinaan Adat dan Istiadat, yang mana menyatakan bahwa aparat penegak hukum memberikan kesempatan agar sengketa/perselisihan diselesaikan terlebih dahulu secara adat di Gampong/Kampung atau nama lainnya. Artinya setiap tindak pidana ringan wajib diselesaikan terlebih dahulu melalui peradilan Gampong atau Kampung.

\footnotetext{
${ }^{9}$ Keputusan Bersama Gubernur Aceh, Kepala Kepolisian Daerah Aceh Dan Ketua Majelis Adat Aceh Nomor : 189/677/2011, 1054/MAA/XII/2011, B/121/I/2012 tentang Penyelenggaraan Peradilan Adat Gampong Dan Mukim Atau Nama Lain Di Aceh

10 Pasal 1 huruf f Qanun Aceh Tengah Nomor 10 Tahun 2002 tentang Hukum Adat Gayo

11 Pasal 13 ayat (1) Qanun Aceh Nomor 9 Tahun 2008 tentang Pembinaan Kehidupan Adat Dan Adat Istiadat
} 


\section{Rumusan Masalah}

Berdasakan uraian latar belakang masalah di atas maka perumusan masalahnya, pertama, bagaimanakah efektivitas penyelesaian tindak pidana ringan melalui sarak opat di Kabupaten Aceh Tengah. Kedua, apakah kendala yang dihadapi sarak opat dalam penyelesaian tindak pidana ringan di Kabupaten Aceh Tengah?

\section{Tujuan Penelitian}

Adapun tujuan penelitian ini, pertama, untuk mengetahui efektivitas penyelesaian tindak pidana ringan melalui sarak opat di Kabupaten Aceh Tengah. Kedua, untuk mengetahui apakah kendala yang dihadapi sarak opat dalam penyelesaian tindak pidana ringan di Kabupaten Aceh Tengah

\section{Metode Penelitian}

Jenis penelitian ini adalah penelitian hukum empiris atau penelitian hukum sosiologis. Penelitian hukum empiris, yang deteliti pada awalnya adalah data sekunder yang kemudian dilanjutkan dengan penelitian pada data primer di lapangan. ${ }^{12}$ Dengan demikian penelitian hukum yuridis empiris tetap bertumpu pada data sekunder sebagai das solen dan data primer sebagai das sein.

Jenis data yang digunakan dalam penelitian ini yakni penelitian pustaka (Library Research) dan penelitian lapangan (Field Research). Penelitian pustaka (library reserach) dilakukan untuk memperoleh data sekunder yang bersumber dari bahan-bahan hukum yang terdiri dari: Bahan hukum primer, yaitu bahan hukum yang menjadi dasar pokok yang mempunyai sifat mengikat, yang berupa: UndangUndang Dasar Tahun 1945, Undang-Undang Nomor 11 Tahun 2006 tentang Pemerintahan Aceh, Qanun Aceh Nomor 9 Tahun 2008 tentang Pembinaan Kehidupan Adat Dan Adat Istiadat, Qanun Aceh Nomor 10 Tahun 2008 tentang Lembaga Adat, Qanun Kabupaten Aceh Tengah Nomor 10 Tahun 2002 tentang Hukum Adat Gayo, Peraturan Gubernur Aceh Nomor 60 Tahun 2013 tentang Pelaksanaan Penyelesaian Sengketa/Perselisihan Adat Dan Istiadat, Surat Keputusan Bersama Antara Gubernur, Kapolda, Ketua Majelis Adat Aceh Nomor

${ }^{12}$ Soerjono Soekanto, Pengantar Penelitian Hukum, UI Press, Jakarta, 2010, hlm. 52. 
189/677/2011, 1054/MAA/XII/2011 dan Nomor B/121/1/2012 tentang Kesepakatan Penyelesaian Perkara Tindak Pidana Ringan Melalui Peradilan Adat Gampong.

Bahan hukum sekunder, maka dibutuhkan bahan berupa buku, karya ilmiah dan hasil-hasil seminar yang relevan dengan penelitian ini serta pendapat ahli yang dilengkapi dengan data primer berupa hasil wawancara dengan instansi terkait. Bahan Hukum Tersier atau Bahan hukum penunjang yang mencakup bahan yang memberi petunjuk-petunjuk dan penjelasan terhadap bahan hukum primer, sekunder seperti kamus umum, kamus hukum, majalah dan jurnal ilmiah, serta bahan-bahan di luar bidang hukum yang relevan dan dapat dipergunakan untuk melengkapi data yang diperlukan dalam penelitian. Penelitian lapangan (field research) dilakukan untuk memperoleh data primer dengan cara wawancara secara langsung kepada responden dan informan. Adapun responden penelitian ini adalah: 5 orang Reje (Kepala) Kampung Di Wilayah Kabupaten Aceh Tengah, sedangkan Informan dalam penelitian ini adalah: 2 orang penyidik Kepolisian Resort Kabupaten Aceh Tengah, dan 3 orang Majelis Adat Gayo Kabupaten Aceh Tengah.

Metode pengumpulan data melalui yang dilakukan, dengan cara melakukan penelitian langsung kelapangan dengan metode wawancara yaitu mengajukan pertanyaan secara langsung kepada narasumber guna memperoleh data yang diperlukan berkaitan dengan permasalahan. Untuk mendapat data sekunder, penulis melakukan pengkajian terhadap bahan-bahan kepustakaan atau sumber data lainnya. Selain itu mencatat mengutip dan meresume teori-teori dan peraturan perundang-undangan yang berhubungan objek penelitian.

\section{Hasil Penelitian dan Pembahasan}

\section{Efektifitas Penyelesaian Tindak Pidana Ringan Melalui Sarak Opat di Kabupaten Aceh Tengah}

Penyelesaian perkara atau sengketa dalam masyarakat dikenal ada dua macam penyelesaian, yang pertama dikenal dengan penyelesaian secara pengadilan (litigasi) dan yang kedua dikenal dengan secara luar pengadilan (non litigasi). Penyelesaian sengketa secara litigasi adalah penyelesaian sengketa di peradilan, seperti badan peradilan umum, Peradilan Agama atau Mahkamah 
Syariah, Peradilan Militer, dan Peradilan Tata Usaha Negara (PTUN). Penyelesaian sengkata secara non litigasi adalah penyelesaian perkara atau sengketa di luar peradilan atau sering disebut dengan Alternative Dispute Resolution (ADR). ${ }^{13}$

Menurut I Wayan Wiryawan dan I Ketut Artadi, penyelesaian sengketa secara litigation (pengadilan), sebagian besar tugasnya adalah menyelesaikan sengketa dengan menjatuhkan putusan (constitutive) misalnya menjatuhkan putusan atas sengketa waris, perbuatan melawan hukum dan sebagian kecil tugasnya adalah penangkalan sengketa dengan menjatuhkan penetapan pengadilan (deklaratoir) misalnya penetapan wali, penetapan anak angkat dan lain-lain. ${ }^{14}$ Non litigasi sebagai kebalikan dari litigasi (argumentum analogium) adalah untuk menyelesaikan sengketa di luar pengadilan melalui perdamaian dan penangkalan sengketa dengan perancangan-perancangan kontrak yang baik. Penyelesaian sengketa secara non litigasi meliputi bidang yang sangat luas bahkan mencakup seluruh aspek kehidupan yang dapat diselesaikan secara hukum. ${ }^{15}$

Dalam perkembangan pembaharuan hukum pidana di berbagai negara ada kecenderungan kuat untuk menggunakan mediasi penal sebagai salah satu alternatif penyelesaian masalah di bidang hukum pidana. ${ }^{16}$ Walaupun pada umumnya penyelesaian sengketa di luar pengadilan hanya dikenal dalam perkara perdata, namun dalam prakteknya perkara pidana sering juga diselesaikan di luar pengadilan melalui diskresi aparat penegak hukum atau melalui lembaga adat yang ada di dalam masyarakat. Penanganan suatu kasus melalui musyawarah (mediasi) sebenarnya ditransplantasi dari kearifan lokal yang telah lama dipraktikkan oleh masyarakat adat di tanah air, hanya saja istilah yang digunakan berbeda, seperti pegundem di Lombok, rembug desa di Jawa, rungkun di Batak Karo, dan paruman di Bali. ${ }^{17}$ Penyelesaian dengan jalan damai merupakan nilai yang terpuji dan dijunjung tinggi sehingga mendapat dukungan yang kuat. ${ }^{18}$

\footnotetext{
${ }^{13}$ Rachmadi Usman, Mediasi Di Pengadilan: Dalam Teori dan Praktek, Sinar Grafika, Jakarta, 2012, hlm. 8.

${ }^{14}$ I Wayan Wiryawan dan I Ketut Artadi, Penyelesaian Sengketa Di Luar Pengadilan, Udayana University Press, Denpasar-Bali, 2010, hlm. 3.

${ }^{15}$ Ibid., hlm. 4.

${ }^{16}$ Barda Nawawi Arief, Mediasi Penal Penyelesaian Perkara Pidana di Luar Pengadilan, Cetakan ke-4, Penerbit Pustaka Magister, Semarang, 2012, hlm. 3

${ }_{17}$ I Made Widnyana, Hukum Pidana Adat dalam Pembaharuan Hukum Pidana, PT. Fikahati Aneska, Jakarta, 2013, hlm. 107

${ }^{18}$ Soepomo, Bab-Bab Tentang Hukum Adat, Pradnya Paramita, Jakarta, 1986, hlm. 113
} 
Dibandingkan daerah lain, dengan dukungan pranata peraturan di tingkat daerah serta segala keistimewaan yang dimiliki kiranya posisi Aceh memiliki peluang lebih besar untuk terus dapat menjaga keberlangsungan upaya pelestarian atas hukum adat dan peradilan adat. ${ }^{19} \mathrm{Di}$ Aceh penyelesaian perselisihan di dalam masyarakat baik perkara perdata dan pidana yang ringan diselesaikan melalui lembaga adat (peradilan adat), sebagaimana diamanatkan dalam Pasal 98 ayat (1) dan (2) Undang-Undang Nomor 11 Tahun 2006 tentang Pemerintahan Aceh menyebutkan bahwa:

(1)Lembaga adat berfungsi dan berperan sebagai wahana partisipasi masyarakat dalam penyelenggaraan Pemerintahan Aceh dan pemerintahan kabupaten/kota di bidang keamanan, ketenteraman, kerukunan, dan ketertiban masyarakat.

(2)Penyelesaian masalah sosial kemasyarakatan secara adat ditempuh melalui lembaga adat.

Kewenangan lembaga adat, lebih lanjut diatur dalam Pasal 4 Qanun Aceh Nomor 10 Tahun 2008 tentang Lembaga Adat, yaitu :

a. Menjaga keamanan, ketentraman, kerukunan, dan ketertiban masyarakat;

b. Membantu Pemerintah dalam pelaksanaan pembangunan;

c. Mengembangkan dan mendorong partisipasi masyarakat;

d. Menjaga eksistensi nilai-nilai adat dan adat istiadat yang tidak bertentangan dengan syari' at Islam;

e. Menerapkan ketentuan adat;

f. Menyelesaikan masalah sosial kemasyarakatan;

g. Mendamaikan sengketa yang timbul dalam masyarakat; dan

h. Menegakkan hukum adat.

Qanun tersebut diperkuat dengan berlakunya Peraturan Gubernur Aceh Nomor 60 Tahun 2013 tentang Pelaksanaan Penyelesaian Sengketa/Perselisihan Adat Dan Istiadat, kemudian diberlakukannya Surat Keputusan Bersama Antara Gubernur, Kapolda, Ketua Majelis Adat Aceh Nomor 189/677/2011, 1054/MAA/XII/2011 dan Nomor B/121/1/2012 tentang Kesepakatan Penyelesaian Perkara Tindak Pidana Ringan Melalui Peradilan Adat Gampong.

Dalam masyarakat Gayo, lembaga adat yang bertanggungjawab dalam pelaksanaan hukum adat Gayo dan sebagai peradilan adat adalah lembaga adat

${ }^{19}$ Nanda Amalia, Mukhlis, dan Yusrizal, "Model Penyelesaian Sengketa dan Peradilan Adat di Aceh”, artikel dalam Jurnal Hukum IUS QUIA IUSTUM, Volume 25 No. 1, Januari 2018, hlm. 167. 
sarak opat, hal ini secara tegas diatur dalam Pasal 9 ayat (2) huruf b Qanun Kabupaten Aceh Tengah Nomor 10 Tahun 2002 tentang Hukum Adat Gayo, menyebutkan bahwa "sarak opat mempunyai tugas menyelesaikan perselisihan berdasarkan hukum adat, adat istiadat dan kebiasaan-kebiasaan". Lebih lanjut penyelesaian perkara atau perselisihan melalui lembaga sarak opat di Kabupaten Aceh Tengah diperkuat dengan Surat Keputusan Bersama Bupati Kabupaten Aceh Tengah, Ketua DPRK dan Ketua MAA Kabupaten Aceh Tengah Nomor 373 Tahun 2008, Nomor 320/DPRK/2008, Nomor Polisi B/810/ 2008 Res Aceh Tengah dan Nomor 110/MAA/V/2008 tentang Kesepakatan Penyelesaian Perkara Tindak Pidana Ringan Melalui Peradilan Adat Kampung.

Sarak opat telah ada sejak suku Gayo berada di Nusantara ini. Lembaga adat "sarak opat" dalam masyarakat Gayo tetap dipertahankan, dimanfaatkan, dipelihara, diberdayakan sesuai dengan hukum adat yang tumbuh dan berkembang dalam masyarakat, karena lembaga adat merupakan suatu wadah untuk menampung aspirasi masyarakat, selain itu sebagai wadah bermusyawarah tentang hal-hal yang berkaitan dengan adat. ${ }^{20}$ Hakim Aman Pinan mengatakan, latar belakang munculnya lembaga sarak opat secara internal adalah Masyarakat Gayo tidak bisa terlepas dari adat-istiadat dan budaya mereka sendiri. Mereka hidup bertalian erat dengan masalah adat istiadatnya. Para leluhur pada zamannya, sehingga adat mereka pegang sebagai panutan, pedoman dan undangundang. Maka untuk menjaga, melindungi, menjalankan dan menegakkan adat budaya itu dalam aspek kehidupan maka masyarakat Gayo harus ada lembaga yang bertanggung jawab yaitu lembaga sarak opat. ${ }^{21}$

M. Yusin Saleh menyatakan, sebelum lahirnya Qanun Aceh dan Peraturan Gubernur, di Kabupaten Aceh Tengah telah dikeluarkan Qanun Kabupaten Aceh Tengah Nomor 10 Tahun 2002 tentang Hukum Adat Gayo, yang mana telah mengatur tindak pidana atau kejahatan menurut hukum adat Gayo dan dapat diselesaikan menurut adat melalui lembaga adat sarak opat, yaitu:22

${ }^{20}$ Syukri UR, Sarak Opat Sistem Pemerintahan Tanah Gayo Dan Relevansinya Terbadap Pelaksanaan Otonomi Daerah, Hijri Pustaka Utama, Jakarta, 2006, hlm. 126

${ }^{21}$ Hakim Aman Pinan, Hakikat Nilai-Nilai Budaya Gayo, Cet. I, Takengon, 1998, hlm. 12.

22 M. Yusin Saleh, Ketua Majelis Adat Gayo Kabupaten Aceh Tengah, Wawancara, Tanggal, 15 Mei 2018. 
1. Nahma teraku (penghinaan), meliputi segala perbuatan yang menimbulkan rasa tidak senang atau tidak nyaman yang merendahkan harkat martabat kemanusiaan.

2. Belang terpancang/diniye terlangis (Pencurian), Tindak pidana pencurian meliputi, pencurian dalam keluarga, pencurian ringan, pencurian yang dilakukan anak dibawah umur, dan pencurian ternak.

3. Malu tertawan (penculikan anak gadis), anak gadis dalam masyarakat gayo ditempatkan pada kedudukan yang tinggi bahkan semasa mereka masih gadis dinyatakan sebagai anakni edet, kedudukannya seolah-olah anak-anak Raja yang mendapat perlindungan hukum tidak boleh diganggu. Barang siapa yang melarikan anak gadis, orang tua gadis dengan kekuatan hukum adat nahma taraku berhak membela anak gadisnya, bahkan membunuh orang yang melarikan/menawan anak gadisnya apabila orang yang melarikannya itu belum sampai di tangan pemangku adat, sedangkan orang tua/ keluarga yang membunuhnya itu bebas dari tuntutan hukum, bukan itu saja, bahkan bila orang yang melarikan gadis itu sampai ke daerah luar tanah Gayo, atau di pulau mana pun ia berada kalau dapat dijumpai oleh keluarga si gadis, ia dapat dibunuh oleh keluarga si gadis dengan tidak ada sanksinya.

4. Penganiayaan ringan sebagaimana yang diatur dalam Pasal 352 ayat (1) Kitab Undang-Undang Hukum Pidana (KUHP) dapat diselesaikan oleh sarak opat, yaitu penganiayaan yang tidak menimbulkan pendarahan berat atau tidak menimbulkan cacat fisik atau psikis.

5. Pengancaman sebagaimana yang diatur dalam Pasal 368 Kitab Undang-Undang Hukum Pidana (KUHP) yang meliputi segala bentuk ancaman melalui perbuatan, perkataan, simbol-simbol tertentu tanpa kekerasan fisik yang mengancam keselamatan jiwa atau harta benda milik seseorang.

6. Perzinaan (Perbuatan Sumang), sebagiamana dalam Pasal 14 Qanun Kabupaten Aceh Tengah Nomor 10 Tahun 2002 tentang Hukum Adat Gayo, menjelaskan tentang perbuatan zina, yaitu:

a) Roba, yaitu perbuatan zina yang dilakukan seseorang dalam satu kampung;

b) Mengeroba, yaitu perbuatan zina yang dilakukan oleh seseorang berlainan kampung; 
c) Angkara, yaitu kejahatan/perbuatan zina dalam satu kampung;

d) Masukkara, yaitu perbuatan yang tidak patut seperti berzina dengan orang kampung lain.

M. Yusin Saleh menambahkan, jenis perkara/perselisihan ringan yang dikeluarkan oleh pemerintah daerah Kabupaten Aceh Tengah melalui Qanun Nomor 10 Tahun 2002 tentang Hukum Adat Gayo pada dasarnya sama dengan Qanun Aceh Nomor 10 Tahun 2008 tentang Lembaga Adat dan Peraturan Gubernur Aceh Nomor 60 Tahun 2013 tentang Pelaksanaan Penyelesaian Sengketa/Perselisihan Adat Dan Istiadat yang dikeluarkan oleh Pemerintah Aceh. Dengan dikeluarkannya peraturan/qanun ini pelaksanaan penyelesaian perkara melalui lembaga adat sudah mempunyai landasan hukum yang kuat. ${ }^{23}$

Jenis tindak pidana ringan diselesaikan oleh lembaga adat sarak opat yang tersebut diatas, jika dikaitkan dengan Kitab Undang-Undang Hukum Pidana (KUHP) ditentukan berdasarkan ancaman pidananya, sedangkan ancaman tindak pidana yang menjadi ukuran dalam acara pemeriksaan tindak pidana ringan, diatur dalam Pasal 205 ayat (1) Kitab Undang-Undang Hukum Acara Pidana, yaitu:

a. Tindak pidana yang ancaman pidananya paling lama 3 bulan penjara atau kurungan;

b. Atau denda sebanyak-banyaknya Rp. 7500 ,- dan

c. Penghinaan ringan yang dirumuskan dalam Pasal 315 Kitab UndangUndang Hukum Pidana. ${ }^{24}$

Proses penyelesaian perkara atau perselisihan melalui sarak opat tidak diatur secara jelas dalam Qanun Nomor 9 Tahun 2002 tentang Hukum Adat Gayo. Proses penyelesaiannya perselisihan atau perkara pidana yang dilakukan lembaga sarak opat tidaklah sama dengan yang dilakukan pengadilan formal, seperti halnya pada pengadilan umum yang memiliki hakim, jaksa, panitera. Namun dalam pelaksanaannya proses penyelesaian perkara melalui lembaga adat di Aceh mengenal upaya hukum yang dilakukan oleh pihak yang berperkara.

Menurut M. Yusin Saleh, proses penyelesaian perkara pidana ringan di tingkat kampung pada dasarnya diselesaikan terlebih dahulu oleh kepala dusun,

${ }_{23}$ M. Yusin Saleh, Ketua Majelis Adat Gayo Kabupaten Aceh Tengah, Wawancara, Tanggal, 15 Mei 2018. 38.

${ }^{24}$ M. Yahya Harahap, Pembahasan Permasalahan Dan Penerapan KUHAP, Pustaka Kartini, Jakarta, 2003, hlm. 
apabila kepala dusun tidak mampu menyelesaikannya, maka perkara itu akan dilimpahkan kepada reje kampung, selanjutnya apabila reje kampung juga tidak mampu menyelesaikannya, maka kasus ini akan diselesaikan secara bersama-sama oleh lembaga adat sarak opat. Namun dalam prakteknya, proses penyelesaian perkara ditingkat kampung langsung diselesaikan oleh lembaga adat sarak opat. ${ }^{25}$

Hal senada diungkapkan oleh Jamaluddin, proses penyelesaian perkara melalui sarak opat dilakukan secara sederhana dengan lebih menekankan aspek musyawarah mufakat untuk mencapai suatu perdamaian dari pihak yang berselisih sebagaimana dalam pepatah gayo mengatakan "keramat mupakat behu berdedele" yaitu mufakat adalah salah satu ketentuan yang berlaku dalam masyarakat Gayo. Oleh karena itu, sarak opat wajib hukumnya melaksanakan musyawarah demi mencapai kemaslahatan umat. ${ }^{26}$

Hal yang senada dikemukakan Ibnu Hadjar Laut Tawar, lembaga adat sarak opat dalam mengambil setiap keputusan terhadap perselisihan/sengketa yang terjadi di masyarakat berdasarkan asas kesepakatan demokrasi, yang terdiri dari:

1) Rapat sara ine yaitu musyawarah keluarga terdekat, atau musyawarah satu keturunan secara patrilineaal (berdasarkan garis keturunan bapak), musyawarah seperti ini disebut juga "begenap" yaitu musyawarah pertama suatu keluarga untuk membicarakan masalah perkawinan, kekerabatan dan lain-lain.

2) Genap sudere yaitu musyawarah famili baik kerabat yang jauh maupun kerabat dekat dan tetangga.

3) Pakat jeroh yaitu memutuskan sesuatu persoalan dengan baik

4) Begenap bise yaitu memperoleh kata sepakat melalui musyawarah saudara, atau perundingan antara kerabat-kerabat yang dekat maupun yang sudah jauh hubungan, misalnya satu belah (clan) baik mengenai rencana perkawinan, kekerabatan dan kemasyarakatan lainnya.

5) Bersiijin-ijinen setelah selesai pelaksanaan musyawarah dan demokrasi, mereka saling memohon maaf lahir dan batin. ${ }^{27}$

Mengukur efektivitas hukum diperlukan beberapa aspek yang mendukung yang menunjang setiap kegiatan penegakan hukum. Menurut Soerjono Soekanto, teori efektivitas hukum adalah bahwa efektif tidaknya suatu hukum ditentukan oleh faktor hukumnya itu sendiri (undang-undang), faktor penegak hukum yakni

\footnotetext{
${ }^{25}$ M. Yusin Saleh, Ketua Majelis Adat Gayo Kabupaten Aceh Tengah, Wawancara, Tanggal, 15 Mei 2018 ${ }^{26}$ Jamaluddin, Sekretaris Majelis Adat Gayo Kabupaten Aceh Tengah, Wawancara, Tanggal 15 Mei 2018

${ }^{27}$ Ibnu Hadjar Laut Tawar, Tokoh Adat Gayo, Wawancara, Tanggal 17 Mei 2018.
} 
pihak-pihak yang membentuk maupun menerapkan hukum, faktor sarana atau fasilitas yang mendukung penegakan hukum, faktor masyarakat yakni lingkungan di mana hukum tersebut berlaku atau diterapkan, faktor kebudayaan yakni sebagai hasil karya, cipta, dan rasa yang didasarkan pada karsa manusia di dalam pergaulan hidup. ${ }^{28}$ Hubungan antara eksistensi hukum dengan efektifitasnya berarti bahwa hukum tertentu mencapai tujuan, artinya bahwa hukum tersebut benar-benar berlaku dan berfungsi. ${ }^{29}$

Berdasarkan data yang diperoleh dari Reserse Kriminal Kepolisian Resort Kabupaten Aceh Tengah, perkara tindak pidana ringan yang seharusnya menjadi kewenangan lembaga adat sarak opat diselesaikan oleh kepolisian masih tinggi, sebagaimana dapat dilihat dari tabel di bawah ini:

\section{Tabel 1}

\section{Jumlah Tindak Pidana Ringan yang Diselesaikan Kepolisian} Pada Tahun 2017-2018

\begin{tabular}{clc}
\hline No & \multicolumn{1}{c}{ Jenis Kasus } & Jumlah Kasus \\
\hline 1 & KDRT & 8 \\
2 & Pencurian Ternak & 1 \\
3 & Pencurian Ringan & 4 \\
4 & Kecelakaan Lalu Lintas Ringan & 2 \\
5 & Penganiayaan Ringan & 2 \\
\hline \multicolumn{2}{c}{ Jumlah } & $\mathbf{2 2}$ \\
\hline
\end{tabular}

Sumber : Reskrim Kepolisian Resort Kabupaten Aceh Tengah Tahun 2018

Dari tabel di atas dapat dilihat bahwa belum efektifnya atau belum berjalannya penyelesaian tindak pidana ringan melalui lembaga adat sarak opat sebagaimana diamanatkan dalam Qanun Nomor 9 Tahun 2008 tentang Lembaga Adat di tingkat Kampung di Kabupaten Aceh Tengah. Masih adanya jenis perkara pidana yang merupakan kewenangan lembaga adat sarak opat dalam penyelesaiannya, namun di tangani oleh kepolisian.

Hal ini senada yang di ungkapkan oleh M. Yusin Saleh, penyelesaian tindak pidana ringan sebagaimana diatur dalam Qanun Nomor 9 Tahun 2008 tentang lembaga adat sarak opat belumlah efektif, masyarakat lebih percaya penyelesaian perkara atau perselisihan yang terjadi di laporkan ke pihak kepolisian. Seperti

\footnotetext{
${ }^{28}$ Soerjono Soekanto, Masalah ..., Op. Cit., hlm. 8

${ }^{29}$ Ibid., hlm, 5.
} 
perkara pidana pencurian ternak kerbau yang terjadi di Kampung Jalil Kecamatan Bintang, kami telah memfasilitasi para pihak yang berperkara agar penyelesaiannya di selesaikan melalui lembaga sarak opat, namun korban melaporkan kami ke pihak kepolisian seolah-olah kami berpihak kepada pelaku pencurian.

Peran lembaga adat sarak opat dalam penyelesaian perkara pidana kurang mendapatkan perhatian dari masyarakat itu sendiri, masih adanya masyarakat yang melaporkan langsung kepada Kepolisian perkara pidana ringan sebagimana diatur dalam Qanun Aceh Nomor 9 Tahun 2008 tentang Lembaga Adat. Fakta tersebut menjadi salah satu bukti konkret yang menunjukkan bahwa Qanun tersebut belum berjalan maksimal. Masyarakat yang menjadi korban dari perbuatan pidana lebih percaya kepada aparat penegak hukum (kepolisian) dibandingkan dengan pola penyelesaian melalui lembaga adat sarak opat.

Menurut Wahyu Melala, pada dasarnya semua ketentuan penyelesaian tindak pidana ringan yang dapat diselesaikan lembaga adat sarak opat yang diatur dalam qanun dan selanjutnya diperjelas dalam peraturan gubernur Aceh sudah dilaksanakan oleh jajaran Kepolisian Kabupaten Aceh Tengah, namun masih ada juga masyarakat yang melaporkan perkara pidana yang seharusnya diselesaikan oleh sarak opat ke pihak kepolisian. ${ }^{30}$

Fadhillah Aditya Pratama menambahkan, tindakan kepolisian jika ada masyarakat yang membuat laporan atau pengaduan perkara pidana yang seharusnya diselesaikan oleh lembaga adat sarak opat, tidak akan langsung memproses laporan atau pengaduan masyarakat tersebut, namun meminta kepada masyarakat untuk diselesaikan terlebih dahulu melalui lembaga adat sarak opat. ${ }^{31}$

${ }^{30}$ Wahyu Melala, Penyidik Tindak Pidana Umum Kepolisian Resort Kabupaten Aceh Tengah Wawancara, Tanggal, 22 Mei 2018

31 Fadhillah Aditya Pratama, Kasat Reserse Kriminal Kepolisian Resort Kabupaten Aceh Tengah Wawancara, Tanggal, 22 Mei 2018 


\section{Kendala yang Dihadapi Sarak Opat dalam Penyelesaian Tindak Pidana Ringan} di Kabupaten Aceh Tengah

Penyelesaian perkara atau perselisihan di dalam masyarakat selalu diupayakan penyelesaiannya melalui hukum adat, hal ini disebabkan karena hukum adat bagi masyarakat adat Gayo sudah menyatu dengan masyarakat, dan tidak bertentangan dengan kaidah-kaidah, karena adat dan hukum (edet urum ukum) tidak dapat dipisahkan atau sangat berpadu dalam menyelesaikan kasus hukum pada masyarakat Gayo. Penyelesaian perkara melalui hukum adat betulbetul dapat dirasakan keadilan oleh masyaraakat. Selain prosesnya cepat dan tidak berlarut-larut juga tidak menimbulkan rasa dendam di antara para pihak yang bertikai serta dapat mengembalikan keseimbangan di dalam masyarakat secara keseluruhan. Dalam menyelesaikan perkara pidana melalui hukum adat selalu dikedepankan sifat kekeluargaan, dan prinsip perdamaian. Berdasarkan asas rukun, tentram, dan asas keiklasan masyarakat menemukan kedamaian hidup yang baik di dalam bermasyarakat. Dalam sistem hukum adat yang ingin dicapai adalah kerukunan para pihak yang bertikai, kerukunan masyarakat keseluruhan, dan kerukunan masyarakat dengan alam lingkungannya.

M. Yusin Saleh menyatakan, penyelesaian perkara melalui sarak opat memiliki putusan yang menguntungkan kedua belah pihak, berbeda halnya penyelesaian perkara melalui hukum positif, jika pelaku sudah dihukum penjara atau dikenakan sanksi berdasarkan kasusnya belum tentu benar-benar dapat selesai, bahkan akan timbul permasalahan yang baru seperti adanya rasa dendam dari pelaku. ${ }^{32}$

Hukum itu efektif dan ditaati orang karena adanya kesadaran, adanya sanksi, adanya tekanan, lingkungan sosial. Lingkungan sosial yang dimaksud sangat mempengaruhi tumbuhnya motivasi untuk menaati atau melanggar hukum adalah lingkungan terdekat dengan seseorang yaitu orang tua, teman sepermainan, dan kelompok pendidik. ${ }^{33}$ Sementara di lain pihak Koesno menyebutkan bahwa hukum adat itu efektif dan dipatuhi orang karena telah memenuhi asas pantas,

${ }^{32}$ M. Yusin Saleh, Ketua Majelis Adat Gayo Kabupaten Aceh Tengah, Wawancara, Tanggal, 15 Mei 2018

33 Soerjono Soekanto, Efektivitasi Hukum Dan Peranan Sanksi, Remadja Karya, Bandung, 1988, hlm. 60. 
adil, patut dan laras. ${ }^{34}$ Penyelesaian konflik perlu memperhatikan hukum adat yang berlaku di masyarakat. Sebab jika hukum adat masih sangat kuat dipertahankan dalam masyarakat maka mekanisme hukum adat akan menjadi faktor penentu keberhasilan penyelesaian konflik. ${ }^{35}$

Dalam proses penyelesaian tindak pidana ringan melalui lembaga adat sarak opat, tentunya terdapat kendala-kendala yang dihadapi oleh sarak opat, yaitu :

\section{Kurangnya Pemahaman Perangkat Lembaga Adat Sarak Opat}

Pengetahuan dan pemahaman lembaga adat sarak opat sebagai lembaga peradilan adat akan sangat berpengaruh terhadap penyelesaian perkara atau perselisihan yang terjadi di dalam masyarakat. Menurut Jamaluddin, pemahaman terhadap kewenangan perangkat sarak opat dalam menyelesaikan tindak pidana ringan masih sangat minim, sehingga penyelesaian tindak pidana ringan yang terjadi di Kampung selama ini diselesaikan di tingkat kepolisian. ${ }^{36}$

Jamaluddin menambahkan, dalam menyelesaikan perselisihan/perkara yang terjadi dalam masyarakat, lembaga adat sarak opat dalam hal ini reje kampung bersikap pasif, tidak akan mendatangi masyarakat yang sedang berkonflik/berperkara kecuali telah adanya laporan dari masyarakat tersebut. Akibat proaktifnya lembaga adat sarak opat dalam hal ini reje kampung maka ada beberapa perkara/sengketa yang dibiarkan begitu saja tidak diselesaikan. ${ }^{37}$

\section{Sanksi Adat Tidak Memberikan Efek Jera Terhadap Pelaku}

Putusan peradilan adat merupakan hasil musyawarah dalam rangka mencapai kedamaian di antara kedua belah pihak. Oleh karena itu putusannya berupa sanksi mulai dari sanksi yang sangat ringan seperti menasihati sampai pengusiran dari Kampung. Pada saat mencapai suatu keputusan pentinglah digaris bawahi bahwa kedua belah pihak harus menyetujui secara bebas dan mandiri sanksi atau hukuman yang akan diberikan. Pasal 16 Qanun Aceh Nomor 9 Tahun 2008 tentang Lembaga Adat menyebutkan, bahwa jenis-jenis penyelesaian

${ }^{34}$ Moh. Koesnoe, Catatan Terbadap Hukum Adat Dewasa Ini, Erlangga University Press, Surabaya, 1978, hlm. 39.

35 Trisno Raharjo, "Mediasi Pidana Dalam Ketentuan Hukum Pidana Adat", artikel dalam Jurnal Hukum IUS QULA IUSTUM, Volume 17 No. 3, Juli 2010, hlm. 497.

${ }^{36}$ Jamaluddin, Sekretaris Majelis Adat Gayo Kabupaten Aceh Tengah, Wawancara, Tanggal, 15 Mei 2018

${ }^{37}$ Jamaluddin, Sekretaris Majelis Adat Gayo Kabupaten Aceh Tengah, Wawancara, Tanggal, 15 Mei 2018 
sengketa dan sanksi yang dapat dijatuhkan berupa: a) Teguran; b) Pernyataan maaf dihadapan orang banyak di meunasah atau mesjid diikuti dengan acara peusijuk; c) Denda; d) Ganti kerugian; e) Dikucilkan oleh masyarakat gampong; f) Dikeluarkan dari masyarakat gampong; g) Pencabutan gelar adat.

Peneliti wawancarai satu orang masyarakat yang juga merupakan korban pencurian ternak kerbau, menyatakan kurang setuju dengan penyelesaian perkaranya melalui lembaga adat sarak opat, karena penyelesaian perkara melalui lembaga adat sarak opat tidak dapat memberi efek jera bagi pelaku, karena denda yang diberikan tidak begitu berat dan tidak sesuai dengan kerugian yang dialami sebagai korban, sehingga pelaku menganggap hukumannya terlalu ringan dan akan mengulangi kejahatan yang sama di kemudian hari. ${ }^{38}$

Pendapat yang berbeda yang disampaikan oleh Junaidi, terkendalanya penyelesaian perkara pidana melalui lembaga adat sarak opat, adanya permintaan yang berlebihan dari korban terhadap pelaku, sehingga pelaku enggan menyelesaikan perkara pidananya melalui lembaga adat sarak opat, korban dalam mengambil setiap keputusan penyelesaian perselisihan adat harus melihat dan mempertimbangkan juga keadaan ekonomi pelaku. ${ }^{39}$

Kenyataan tersebut menunjukkan bahwa tidak semua putusan sarak opat dilaksanakan secara konsisten, masih adanya masyarakat tidak puas terhadap putusan sarak opat. Fakta ini menunjukkan bahwa peran dan fungsi sarak opat pada saat ini telah mengalami perubahan, pada masa dulu sarak opat memiliki kewenangan yang luas dalam menyelesaikan perselisihan yang terjadi di dalam masyarakat baik itu yang berkaitan dengan perkara perdata dan pidana. Bahkan hasil keputusan penyelesaiannya dianggap sah dan memiliki kekuatan hukum, namun saat ini keputusan sarak opat dalam menyelesaikan permasalahan dianggap sah namun tidak memiliki kekuatan hukum. Sehingga kalau ada yang melanggar keputusan yang telah disepakati maka hukuman yang hanya diberikan berupa sanksi sosial.

\footnotetext{
${ }^{38}$ Ridwansyah, Masyarakat Kampung Genuren Kecamatan Bintang Kabupaten Aceh Tengah, Wawancara, Tanggal, 30 Mei 2018 Mei 2018

${ }^{39}$ Junaidi, Reje Kampung Genuren Kecamatan Bintang Kabupaten Aceh Tengah, Wawancara, Tanggal, 30
} 
Tidak Terdokumentasikannya Penanganan Perkara/Kasus oleh Lembaga Adat Sarak Opat

Berkas perkara termasuk surat pejanjian yang berisi keputusan-keputusan adat harus disimpan atau diarsipkan secara aman oleh pemangku adat, hal ini penting dilakukan untuk menjamin dan mempelancar proses peradilan bagi kasuskasus lain serta kasus yang sama terulang kembali, sehingga pemangku adat mempunyai referensi dalam melakukan proses peradilan dan mengambil keputusan-keputusan sengketa adat. ${ }^{40}$ Setiap proses dan keputusan-keputusan yang telah diambil harus dicatat secara akurat dalam dokumen administrasi peradilan adat sebagaimana diamanatkan Dalam Diktum Ketujuh Surat Keputusan Bersama Antara Gubernur, Kapolda Aceh, Majelis Adat Aceh Nomor 189/677/2011, 1054/MAA/XII/2011, Dan Nomor B/121/1/2012 Tentang Penyelenggaraan Peradilan Adat Gampong Atau Nama Lain Di Aceh, menyebutkan bahwa, setiap putusan peradilan adat kampung atau nama lainnya di Aceh dibuat secara tertulis, di tanda tangani oleh Ketua dan Anggota Majelis serta kedua belah pihak yang bersengketa dan tembusannya disampaikan kepada kepala kepolisian sektor (Kapolsek), Camat serta Majelis Adat.

Hasil penelitian menunjukkan bahwa mayoritas lembaga adat sarak opat dalam melaksanakan penyelesaian perkara di Kabupaten Aceh Tengah tidak melakukan pencatatan atau laporan tertulis tentang proses dan hasil penanganan perkara yang ditangani oleh lembaga sarak opat. Menurut M Yusin Saleh, mayoritas lembaga adat sarak opat dalam melakukan proses penyelesaian perkara tidak melakukan pencatatan terhadap perkara yang ditangani, hanya sebatas dilakukan secara kebiasaan masyarakat setempat. ${ }^{41}$

Hal senada juga diungkapkan oleh Zulkifli, selama ini dalam penyelesaian perkara atau kasus-kasus yang diselesaikan sarak opat tidak dilakukan tercatat secara baik dan teratur, bahkan tidak memiliki arsip terhadap perkara yang telah diselesaikan perkaranya di tingkat Kampung. ${ }^{42}$

40 Majelis Adat Aceh dan UNDP, Pedoman Peradilan Adat Di Aceb : Untuk Peradilan Adat Yang Adil Dan Akuntabel, Banda Aceh, Aceh, hlm. 14.

${ }^{41}$ M. Yusin Saleh, Ketua Majelis Adat Gayo Kabupaten Aceh Tengah, Wawancara, Tanggal 15 Mei 2018.

42 Zulkifli, Reje Kampung Kala Nareh Kecamatan Pegasing, Wawancara, Tanggal 29 Mei 2018. 
Berdasarkan hal tersebut di atas, tidak tercatat penangan perkara yang diselesaikan sarak opat, menunjukkan bahwa lembaga adat sarak opat tidak melaksanakan amanah Pasal 19 Peraturan Gubernur Aceh Nomor 60 Tahun 2103 tentang Penyelesaian Sengketa Adat dan istiadat mengatur bahwa, setiap sengketa atau perselesihan yang ditangani oleh lembaga adat harus tercatat dalam Buku Registrasi Perkara, sedangkan putusan peradilan adat harus dibukukan dalam Buku Induk Penyelesaian Perkara.

\section{Kurangnya Koordinasi Lembaga Adat Sarak Opat dengan Pihak Kepolisian.}

Lembaga adat sarak opat mempunyai landasan hukum yang kuat dalam menyelesaikan suatu perkara atau perselisihan yang terjadi di dalam masyarakat, setiap perkara yang terjadi dalam masyarakat diselesaikan terlebih dahulu oleh sarak opat sebagaimana diamanatkan dalam Diktum Kesatu Surat Keputusan Bersama Antara Gubernur, Kapolda Aceh, Majelis Adat Aceh Nomor 189/677/2011, 1054/MAA/XII/2011, dan Nomor B/121/1/2012 tentang Penyelenggaraan Peradilan Adat Gampong Atau Nama Lain Di Aceh, menyebutkan bahwa sengketa atau perselisihan yang terjadi di Kampung yang bersifat ringan sebagaimana dimaksud dalam Pasal 13, Pasal 14 dan Pasal 15 Qanun Aceh Nomor 9 Tahun 2008 tentang Pembinaan Kehidupan Adat dan Istiadat wajib diselesaikan terlebih dahulu melalui peradilan adat.

Menurut Sopian, dalam menangani atau penyelesaian perkara yang terjadi di Kampung, tidak melibatkan pihak kepolisian dalam proses penyelesaian perkara tersebut, dalam penyelesaian perkara yang dilakukan secara formal, proses penyelesaiannya kita serahkan sepenuhnya kepada tokoh adat dan tokoh agama (imem). ${ }^{43}$

\section{Penutup}

Efektifitas penyelesaian tindak pidana ringan melalui sarak opat di Kabupaten Aceh Tengah, berdasarkan data yang diperoleh dari Reserse Kriminal Kepolisian Resort Kabupaten Aceh Tengah, perkara tindak pidana ringan yang seharusnya menjadi kewenangan lembaga adat sarak opat diselesaikan oleh kepolisian masih

${ }^{43}$ Sopian, Reje Kampung Tetunyung Kecamatan Lut Tawar Kabupaten Aceh Tengah, Wawancara, Tanggal 20 September 2018 
tinggi atau belum efektifnya penyelesaian tindak pidana ringan melalui lembaga adat sarak opat sebagaimana diamanatkan dalam Qanun Nomor 9 Tahun 2008 tentang Lembaga Adat di tingkat Kampung di Kabupaten Aceh Tengah. Fakta tersebut menjadi salah satu bukti konkret yang menunjukkan bahwa Qanun tersebut belum berjalan maksimal. Masyarakat yang menjadi korban dari perbuatan pidana lebih percaya kepada aparat penegak hukum (kepolisian) dibandingkan dengan pola penyelesaian melalui lembaga adat sarak opat. Kendala yang dihadapi sarak opat dalam penyelesaian tindak pidana ringan di Kabupaten Aceh Tengah, yaitu: 1). Kurangnya pemahaman perangkat lembaga adat sarak opat; 2). Sanksi adat tidak memberikan efek jera terhadap pelaku; 3). Tidak terdokumentasikannya penanganan perkara/kasus oleh lembaga adat sarak opat; 4). Kurangnya koordinasi lembaga adat sarak opat dengan pihak Kepolisian.

\section{Daftar Pustaka}

\section{Buku}

Arief, Barda Nawawi, Mediasi Penal Penyelesaian Perkara Pidana di Luar Pengadilan, Cetakan ke-4, Penerbit Pustaka Magister, Semarang, 2012.

Harahap, M. Yahya, Pembahasan Permasalahan Dan Penerapan KUHAP, Pustaka Kartini, Jakarta, 2003.

Majelis Adat Aceh dan UNDP, Pedoman Peradilan Adat Di Aceh : Untuk Peradilan Adat Yang Adil Dan Akuntabel, Banda Aceh, Aceh.

Koesno, Moh, Catatan Terhadap Hukum Adat Dewasa Ini, Erlangga University Press, Surabaya, 1978.

Pinan, Hakim Aman, Hakikat Nilai-Nilai Budaya Gayo, Cet. I, Takengon, 1998.

Samosir, Djamanat, Hukum Adat Indonesia Eksistensi Dalam Dinamika Perkembangan Hukum di Indonesia, Nuansa Aulia, Bandung, 2013.

Soekanto, Soerjono, Masalah Kedudukan dan Peranan Hukum Adat, Academica, Jakarta, 1971. , Efektivitasi Hukum Dan Peranan Sanksi, Remadja Karya, Bandung, 1988. Pengantar Penelitian Hukum, UI Press, Jakarta, 2010.

Soepomo, Bab-Bab Tentang Hukum Adat, Pradnya Paramita, Jakarta, 1986.

Syahrizal, Hukum Adat dan hukum Islam di Indonesia, Nadiya Foundation Nanggroe Aceh, Banda Aceh, 2004.

Syukri UR, Sarak Opat Sistem Pemerintahan Tanah Gayo Dan Relevansinya Terhadap Pelaksanaan Otonomi Daerah, Hijri Pustaka Utama, Jakarta, 2006. 
Usman, Rachmadi, Mediasi Di Pengadilan : Dalam Teori dan Praktek, Sinar Grafika, Jakarta, 2012.

Wignjodipoero, Soerojo, Pengantar Dan Asas-Asas Hukum Adat, PT Toko Gunung Agung, Bandung, 1967.

Wiryawan I Wayan, dan I Ketut Artadi, Penyelesaian Sengketa Di Luar Pengadilan, Udayana University Press, Denpasar-Bali, 2010.

Widnyana, I Made Widnyana, Hukum Pidana Adat dalam Pembaharuan Hukum Pidana, PT. Fikahati Aneska, Jakarta, 2013.

\section{Jurnal}

Amalia, Nanda, Mukhlis, dan Yusrizal, "Model Penyelesaian Sengketa dan Peradilan Adat di Aceh", artikel dalam Jurnal Hukum IUS QUIA IUSTUM, Volume 25 No. 1, Januari 2018.

Kamaruddin, "Model Penyelesaian Konflik Di Lembaga Adat", artikel dalam Walisongo: Jurnal Penelitian Sosial Keagamaan, Volume 21 No. 1 Mei 2013.

Raharjo, Trisno, "Mediasi Pidana Dalam Ketentuan Hukum Pidana Adat", artikel dalam Jurnal Hukum IUS QUIA IUSTUM, Volume 17 No. 3, Juli 2010.

Sudrajat, Tedy, Aspirasi "Reformasi Hukum dan Penegakan Hukum Progresif Melalui Hakim Perdamaian Desa", artikel dalam Jurnal Dinamika Hukum, Volume 10 No. 3 Desember 2010.

Ubbe, Ahmad, "Peradilan Adat dan Keadilan Restoratif", artikel dalam Jurnal Rechtsvinding, Volume 2 No. 2 Agustus 2013.

\section{Peraturan Perundang-Undangan}

Undang-Undang Dasar Tahun 1945

Undang-Undang Nomor 11 Tahun 2006 tentang Pemerintahan Aceh

Qanun Aceh Nomor 9 Tahun 2008 tentang Pembinaan Kehidupan Adat Dan Adat Istiadat

Qanun Aceh Nomor 10 Tahun 2008 tentang Lembaga Adat

Qanun Kabupaten Aceh Tengah Nomor 10 Tahun 2002 tentang Hukum Adat Gayo

Peraturan Gubernur Aceh Nomor 60 Tahun 2013 tentang Pelaksanaan Penyelesaian Sengketa/Perselisihan Adat Dan Istiadat

Surat Keputusan Bersama Antara Gubernur, Kapolda, Ketua Majelis Adat Aceh Nomor 189/677/2011, 1054/MAA/XII/2011 dan Nomor B/121/1/2012 tentang Kesepakatan Penyelesaian Perkara Tindak Pidana Ringan Melalui Peradilan Adat Gampong

Surat Keputusan Bersama Bupati Kabupaten Aceh Tengah, Ketua DPRK dan Ketua MAA Kabupaten Aceh Tengah Nomor 373 Tahun 2008, Nomor 320/DPRK/2008, Nomor Polisi B/810/ 2008 Res Aceh Tengah dan Nomor 
110/MAA/V/2008 tentang Kesepakatan Penyelesaian Perkara Tindak Pidana Ringan Melalui Peradilan Adat Kampung. 